\title{
Analysis of the visual safety perception and the clarity of traffic signs and road markings in the presence of road lighting in straight and curved road
}

\author{
Endah Setyaningsih ${ }^{1 *}$, Leksmono Suryo Putranto $^{1}$, Soegijanto ${ }^{3}$, and F.X. Nugroho Soelami ${ }^{3}$ \\ ${ }^{1}$ Tarumanagara University, Doctoral Program of Civil Engineering, 11440 Jakarta, Indonesia \\ ${ }^{2}$ Tarumanagara University, Department of Civil Engineering, 11440 Jakarta, Indonesia \\ ${ }^{3}$ Bandung Institute of Technology, Fac. of Civil and Environmental Engineering, Bandung, Indonesia
}

\begin{abstract}
The presence of road lighting helps a car driver to identify nearby cars. The availability of road lighting can also reduce the occurrence of security disturbances however it has not been considered as the cause of accident. A study was conducted to analyze the visual perception of car drivers toward the road lighting. The research was conducted on Cikampek and Cipularang freeways which include straight and curved road sections. Data collection was conducted using questionnaires as the measurements instrument by asking the participants to watch the video footage of the freeway. The results show that the car drivers feel safer and more clarity in identifying the traffic signs and road marking in the presence of road lighting. Furthermore, yellowish road lighting provides more visual safety perception than white lighting which opposed with other previous studies. This result was obtained from the existing condition in the questionnaires without any control variable.
\end{abstract}

\section{Introduction}

Road lighting has not been considered as an important issue for road safety, especially in Indonesia. There were many road lightings being installed which has not met the requirements. According to Eloholma, et al [1], the main function of road lighting is to maintain human safety and provide good visibility conditions and reduce potential hazards by providing illumination to the objects on the road and around the cars. While Li [2], mentioned that good road lighting is needed to estimate the car speed, monitoring harmful objects beside the car, and keep the distance between the cars. Therefore, the main function of road lighting is to facilitate road users in recognizing objects around them quickly, accurately and comfortably.

\footnotetext{
* Corresponding author : endahs@,ft.untar.ac.id
} 
Several studies have been conducted in Jakarta, Bandung and other cities. The results indicate the presence of uneven illuminance on the road surface, and less or excessive illumination according to the road lighting standards [3-5]. This study provides an overview of car drivers' perceptions to the road lighting, in relation to safety and clarity in identifying traffic signs and road markings. The research was conducted on Cikampek and Cipularang freeways. The freeways have various geometric elements of the road, including uphill slopes, decline, downhill slopes, straight sections and curved sections. A road with such complex geometric elements must consider the visibility of the road users that meet the safety standards [6]. The limitation of visibility may cause an accident. An action to overcome the risk is by installing or improving the road lighting [7].

The Cikampek freeway connects the Jakarta freeway to Cikampek, from the Cawang interchanges $(\mathrm{Km} 0)$ to the Cikampek interchange $(\mathrm{Km} 73)$. While the Cipularang freeway connects Cikampek to Padalarang (KM 121). Currently the Cikampek freeway has become the densest segment of the Trans Java freeways network, connected and integrated with the inner freeway City of Jakarta, Jakarta Outer Ring Road (JORR). Most of Cikampek freeway have 4 lanes in each directions. The busiest freeway at present is the Cikampek freeway with 552,322 cars pass through each day and were dominated by $87 \%$ of vehicle category 1 (light vehicles). The rest were heavy vehicle s ranging from vehicle category II ( 2 axles trucks/ buses) to vehicle caterogy V (5 axles truck trailers) [8]. The Cipularang freeway is crosses many hills and valleys with various road geometrics in the form of successive curved roads, as well as long uphill slopes from Jakarta direction and its reverse downhill slopes direction. The Cipularang freeway is connected directly to Cikampek freeway which is the shortest road from Jakarta to Bandung and vice versa, whiles also the busiest freeway.

The study used the questionnaires as a measuring instrument. The data collection was conducted by asking the participants to watch the video footage of the freeway with straight and curved road section. The videos were captured at night along Cikampek and Cipularang freeway in Jakarta to Bandung direction and its opposite direction using latest technology action camera. The detail locations of the video recording are shown in Table 1 . The video recording was used with the assumption that the freeway condition and circumstances can be represented by the video footage which has the advantages of time saving, costeffectiveness, reduction of accident risk, and controlled numbers of the respondents. However, it also has the disadvantages of the fact that the condition of the roads represented in the video recording will greatly depend on the resolution of the video recordings. In addition, the setting of the experimental room that resembles the conditions in a car is very difficult to obtain and the experience of respondents in a real condition might vary from the testing environment which needs several adjustments. The participants filled out the questionnaires after watching the video recordings with a duration limited between 40 and 60 seconds to avoid the participants from getting exhausted. The conditions in the video recording were in line with the condition in the questionnaires.

The questionnaire consists of 6 conditions for Jakarta to Bandung direction (JB) and Bandung to Jakarta direction (BJ). The definitions for freeway road lighting conditions are:

1. The straight and curved freeway road of condition 1 is the straight and curved freeway roads without road lighting which is intended as a freeway road without installed road lights.

2. The straight and curved freeway road of condition 2 is the straight and curved freeway road with white light road lighting, and the illuminance according to existing condition. 
3. The straight and curved freeway road of condition 2 is the straight and curved freeway road with yellowish light road lighting, and the illuminance according to existing condition.

Table 1 The Locations, road lighting conditions, luminaires arrangements and types of lights which were used in the questionnaires

\begin{tabular}{|c|c|c|c|c|c|c|}
\hline No & $\begin{array}{l}\text { Section of } \\
\text { freeway }\end{array}$ & $\begin{array}{l}\text { Condi } \\
\text { tion }\end{array}$ & $\begin{array}{l}\text { Loca } \\
\text { tion }\end{array}$ & $\begin{array}{c}\text { With } \\
\text { or without light }\end{array}$ & $\begin{array}{l}\text { Lumminaire } \\
\text { arrangements }\end{array}$ & $\begin{array}{l}\text { Type, wattage } \\
\text { lamp and } \\
\text { mounting height }\end{array}$ \\
\hline 1 & $\begin{array}{ll}\text { condition } & 1 \\
\text { straight } & \\
\text { section } & \\
\end{array}$ & JBS1 & $\mathrm{Km} 46$ & without light & - & - \\
\hline 2 & $\begin{array}{ll}\text { condition } & 2 \\
\text { straight } & \\
\text { section } & \\
\end{array}$ & JBS2 & $\mathrm{Km} 35$ & $\begin{array}{l}\text { with } \\
\text { white light }\end{array}$ & single-sided & $\begin{array}{l}\text { LED 90W } \\
9 \mathrm{~m}\end{array}$ \\
\hline 3 & $\begin{array}{ll}\text { condition } & 3 \\
\text { straight } & \\
\text { section } & \\
\end{array}$ & JBS3 & $\mathrm{Km} 47$ & $\begin{array}{l}\text { with } \\
\text { yellowish light }\end{array}$ & central & $\begin{array}{l}\text { HPS } \\
150 \mathrm{~W} \\
11 \mathrm{~m} \\
\end{array}$ \\
\hline 4 & $\begin{array}{l}\text { condition } 1 \\
\text { curved section }\end{array}$ & $\mathrm{JBC} 1$ & $\mathrm{Km} 76$ & without light & - & - \\
\hline 5 & $\begin{array}{l}\text { condition } 2 \\
\text { curved section }\end{array}$ & JBC2 & $\mathrm{Km} 70$ & $\begin{array}{l}\text { with } \\
\text { white light }\end{array}$ & central & $\begin{array}{l}\text { LED } \\
50 \mathrm{~W} \\
7.5 \mathrm{~m}\end{array}$ \\
\hline 6 & $\begin{array}{l}\text { condition } 3 \\
\text { curved section }\end{array}$ & JBC3 & $\begin{array}{l}\mathrm{Km} \\
84\end{array}$ & $\begin{array}{l}\text { with } \\
\text { yellowish light }\end{array}$ & single-sided & $\begin{array}{l}\text { HPS } \\
150 \mathrm{~W} \\
11 \mathrm{~m} \\
\end{array}$ \\
\hline 7 & $\begin{array}{ll}\text { condition } & 1 \\
\text { straight } & \\
\text { section } & \\
\end{array}$ & BJS1 & Km 107 & without light & - & - \\
\hline 8 & $\begin{array}{ll}\text { condition } & 2 \\
\text { straight } & \\
\text { section } & \\
\end{array}$ & BJS2 & $\mathrm{Km} 68$ & $\begin{array}{l}\text { with } \\
\text { white light }\end{array}$ & central & $\begin{array}{l}\text { LED } \\
50 \mathrm{~W} \\
7.5 \mathrm{~m} \\
\end{array}$ \\
\hline 9 & $\begin{array}{ll}\text { condition } & 3 \\
\text { straight } & \\
\text { section } & \\
\end{array}$ & BJS3 & Km 120 & $\begin{array}{l}\text { with } \\
\text { yellowish light }\end{array}$ & single-sided & $\begin{array}{l}\text { HPS } \\
150 \mathrm{~W} \\
11 \mathrm{~m}\end{array}$ \\
\hline 10 & $\begin{array}{l}\text { condition } 1 \\
\text { curved section }\end{array}$ & BJC1 & $\mathrm{Km} 88$ & without light & - & - \\
\hline 11 & $\begin{array}{l}\text { condition } 2 \\
\text { curved section }\end{array}$ & BJC2 & Km 111 & $\begin{array}{l}\text { with } \\
\text { white light }\end{array}$ & single-sided & $\begin{array}{l}\text { LED } \\
50 \mathrm{~W} \\
7.5 \mathrm{~m}\end{array}$ \\
\hline 12 & $\begin{array}{l}\text { condition } 3 \\
\text { curved section }\end{array}$ & BJC3 & Km 97 & $\begin{array}{l}\text { with } \\
\text { yellowish light }\end{array}$ & single-sided & $\begin{array}{l}\text { HPS } \\
150 \mathrm{~W} \\
11 \mathrm{~m}\end{array}$ \\
\hline
\end{tabular}

The questionnaires in this study accommodate 6 variables, including road lighting quality, traffic signs and road markings, which are the road facilities that must be observed by the road users. The variables are Illuminance, Luminance, Glare, Correlated Color Temperature (CCT), traffic signs and road markings. Those variables were compiled as the research instruments and actualized in the 16 questions/statements about the visual perception of the road lighting as shown in Table 2 . 
Table 2 Statement/Question items in the Questionnaire

\begin{tabular}{|l|l|l|l|l|l|l|}
\hline No & Statement/Question item & \multicolumn{5}{|l|}{ Perceived Rate } \\
\hline 1 & Light from the road surface & 1 & 2 & 3 & 4 & 5 \\
\hline 2 & Light from a light source (road light) & 1 & 2 & 3 & 4 & 5 \\
\hline 3 & Light of the surrounding light (another object) & 1 & 2 & 3 & 4 & 5 \\
\hline 4 & Glare from the road surface & 1 & 2 & 3 & 4 & 5 \\
\hline 5 & Glare from the light source (road light) & 1 & 2 & 3 & 4 & 5 \\
\hline 6 & Glare from the ambient light (another object) & 1 & 2 & 3 & 4 & 5 \\
\hline 7 & Glare cause by the car's light from opposite direction & 1 & 2 & 3 & 4 & 5 \\
\hline 8 & Secure & 1 & 2 & 3 & 4 & 5 \\
\hline 9 & Comfortable & 1 & 2 & 3 & 4 & 5 \\
\hline 10 & Evenness of light on the road surface & 1 & 2 & 3 & 4 & 5 \\
\hline 11 & Visibility of road marking & 1 & 2 & 3 & 4 & 5 \\
\hline 12 & Visibility of any potholes & 1 & 2 & 3 & 4 & 5 \\
\hline 13 & Visibility of road median & 1 & 2 & 3 & 4 & 5 \\
\hline 14 & Visibility of other cars & 1 & 2 & 3 & 4 & 5 \\
\hline 15 & Visibility colors of traffic signs & 1 & 2 & 3 & 4 & 5 \\
\hline 16 & Visibility of sign symbol and text & 1 & 2 & 3 & 4 & 5 \\
\hline
\end{tabular}

Note: $1=$ very negative, $5=$ very positive

The design concept used in the research is referred to similar previous studies $[9,10$, 11]. The questionnaire used the Likert measurement scale with 5 stages of measurement from numbers 1 to 5 . Number 1 indicates a very negative condition and number 5 is very positive. For example, a 'light' statement marked with number 1 has the meaning of very dim and number 5 means very 'bright'. However, the statement for 'glare' and 'contrast' is in opposite, which means that number 1 is very "not glare" and very "not contrast" and number 5 is very glare and very contrast. Therefore, the statements of glare and contrast with number 1 means very positive and verynumber 5 means very negative. The participants were asked to provide a circle on the numbers corresponding to their judgement. Questionnaires were filled in a dark room (without lighting from the lights or the sun) which was intended to simulate the condition in a car at a dark night because it is clearer to watch the video in the dark room. The participants used the light from a mobile phone or a flashlight when they were filling the questionnaire in the dark room. Before the completion of the questionnaire, the participants were divided into a group of 3 each, and were explained about each item in the questionnaire and the proper procedure to watch the video and how to play the video. In addition, the introduction to road lighting was also given to the participants to obtain equal judgement on road lighting condition from each participant before the completion of the task. Each group required 30 to 45 minutes to complete the questionnaire including the 10 minutes explanation time. When the participants already finished watching the video, guidance on how to fill out the questionnaire were then given. Food and beverages were provided for the participant after the completion of the data collection.

The population of the study is the car drivers who has been driving through the Cikampek and Cipularang freeways or at least has the experience passing through the freeway as a passenger. The population is categorized as an infinite population as it has a large numbers of population members and not all of them are recognized. The sampling was not entirely random; therefore to obtain the diversity of the data, the randomness of the sample was accomplished by taking various data ranges, such as various age, gender, 
education, occupation, origin and residency. By taking such approach, it is expected that the characteristics of the population become objectively retrieved. The sample was selected to meet the following criteria: a person with a least at least 1 (one) year driving experience, minimum age 20 years, normal vision or has been corrected with glasses [12]. The respondents should pursue at least Senior High School. The research used the reliability test using item-total correlation method and Alpha Cronbach's cut-off minimal $=0.80$ which is considered as good [13]. Discrete variable is used for the measured data because measurement of road lighting has 2 conditions: with or without road lighting, whereas the interval of the measurement is scaled between 1 and 5 [14]. The data processing used parametric statistic method, namely Paired Sample t-test and Pearson correlation test.

\section{Data and result}

\subsection{Analysis of visual safety perception with and without road lighting}

The statistical analysis of the test results for the visual safety perception with or without road lighting on the straight and curved section on the freeway from Jakarta to Bandung (JB) and Bandung to Jakarta (BJ) direction are summarized in Table 3 from 58 participants. The test results of visual safety perception using white lighting versus yellowish lighting are shown in Table 4.

Table 3 The test results of visual safety perception with or without road lighting on the straight and curved section on the freeway in the Jakarta-Bandung (JB) and Bandung-Jakarta (BJ) direction

\begin{tabular}{|c|c|c|c|c|c|}
\hline Pair & Condition & Mean & $\begin{array}{c}\text { Mean } \\
\text { Difference }\end{array}$ & $\begin{array}{c}\text { Significant } \\
\text { Level }\end{array}$ & $\begin{array}{c}\text { Significant? } \\
\text { (Yes/No) }\end{array}$ \\
\hline 1 & JBS1 & 2.54 & - & - & - \\
\hline & JBS2 & 3.76 & -1.22 & $<0,001$ & Yes \\
\hline 2 & JBS1 & 2.54 & - & - & - \\
\hline & JBS3 & 3.43 & $-0,89$ & $<0,001$ & Yes \\
\hline 3 & JBC1 & 2.21 & - & - & - \\
\hline & JBC2 & 3.48 & -1.28 & $<0,001$ & Yes \\
\hline 4 & JBC1 & 2.21 & - & - & - \\
\hline & JBC3 & 3.74 & $-1,53$ & $<0,001$ & Yes \\
\hline 5 & BJS1 & 2.25 & - & - & - \\
\hline & BJS2 & 3.43 & $-1,18$ & $<0,001$ & Yes \\
\hline 6 & BJS1 & 2.25 & - & - & - \\
\hline & BJS3 & 4.00 & $-1,75$ & $<0,001$ & Yes \\
\hline 7 & JBC1 & 2.21 & - & - & - \\
\hline & JBC2 & 3.23 & $-1,02$ & $<0,001$ & Yes \\
\hline 8 & JBC1 & 2.21 & - & - & - \\
\hline & JBC3 & 3.83 & $-1,62$ & $<0,001$ & Yes \\
\hline
\end{tabular}

Note: $\mathrm{S}=$ straight and $\mathrm{C}=$ curved

The results in Table 3 can be divided into 2 directions: Jakarta - Bandung (JB) and Bandung - Jakarta (BJ) with each can be further classified into 2 different types of road, that is: straight and curved road. The analysis of the results will be discussed based on those available outcomes in the following section. 


\subsection{Analysis of Jakarta to Bandung direction}

The result of paired sample t-test for Jakarta-Bandung direction (JB) shows that there is significant difference of visual safety perception on the straight and curved section of the freeway. The similar results were also obtained for the road section with or without road lighting, either for white light or yellowish light as shown in Table 3.

\subsubsection{Straight road with and without road lighting}

On the straight road section, the comparison of the visual safety perception was divided into 2 categories: without road lighting versus road lighting with white light and without road lighting versus road lighting with yellowish light.

The visual safety perception in the straight road without road lighting compared to road lighting with white light shows significant difference with $p<0.001$. The car drivers prefer more to the road using road lighting with white light. The mean of the visual safety perception is 3.76 for road with white light road lighting while the mean of visual safety perception for the road without lighting is 2.54 .

Similar trend also appears in the comparison of the visual safety perception on a straight road without road lighting compared to the road with yellowish road lighting $(p<0.001)$. The mean of visual safety perception for the road without road lighting is 2.54 which is smaller than the mean of visual safety perception for the road having road lighting with yellowish light (3.43).

\subsubsection{Straight road with road lighting using white light versus yellowish light}

Furthermore, the comparison of the visual safety perception between the white light road lighting and yellowish light road lighting shows that the white light road lighting outperforms with mean $=3.76$, while the mean for the yellowish road lighting is 3.43 .

Table 4 shows that the there is no difference of visual safety perception between the lighting with white light and the yellowish light on the Jakarta - Bandung highway $(\mathrm{p}=$ 0.055). The visual safety perception of the car drivers with the white lighting is 3.76 and 3.43 with the yellowish lighting.

\subsubsection{Curved road with and without road lighting}

On the curved road, the comparison of the visual safety perception was also divided into 2 categories as on straight road. The analysis is as follows.

The comparison of curved road without road lighting versus curved road with white light road lighting shows significant difference of visual safety perception between the road without road lighting and the road with white lighting $(\mathrm{p}<0.001)$. Visual safety perception are greater when there is road lighting with white light $($ mean $=3.48)$ compared to the road without lighting (mean $=2.21$ ).

There is also a significant difference in safety and security perception in the curved road when the road without road lighting is compared to the road lighting with yellowish light ( $\mathrm{p}$ $<0.001)$. The visual safety perception is greater when there is road lighting with a yellowish light $($ Mean $=3.74)$ compared to the road without road lighting $($ mean $=2.21)$. 


\subsubsection{Curved road with road lighting using white light versus yellowish light}

The visual safety perception is greater when there is road lighting with a yellowish light $($ Mean $=3.74)$ compared to the road lighting with white light $($ Mean $=3.48)$ which supported by the $\mathrm{p}$ value $=0.017$.

Table 4 The test results of feel visual safety for road lighting using white light versus yellowish light on the straight and curved section on the freeway in the Jakarta-Bandung (JB) and Bandung-Jakarta

(BJ) direction.

\begin{tabular}{|c|c|c|c|c|l|}
\hline Pair & Condition & Mean & $\begin{array}{c}\text { Mean } \\
\text { Difference }\end{array}$ & $\begin{array}{c}\text { Significant } \\
\text { Level }\end{array}$ & \multicolumn{1}{|c|}{ Significant? (Yes/No) } \\
\hline 1 & JBS2 & 3.76 & - & - & - \\
\hline & JBS3 & 3.43 & 0,33 & 0,055 & Yes, using white and yellowish light \\
\hline 2 & JBC2 & 3.48 & - & - & - \\
\hline & JBC3 & 3.74 & $-0,25$ & 0,017 & Yes, using yellowish light \\
\hline 3 & BJS2 & 3.43 & - & - & - \\
\hline & BJS3 & 4.00 & $-0,57$ & $<0,001$ & Yes, using yellowish light \\
\hline 4 & BJC2 & 3.23 & - & - & - \\
\hline & BJC3 & 3.82 & $-0,59$ & $<0,001$ & Yes, using yellowish light \\
\hline
\end{tabular}

Note: $\mathrm{S}=$ straight and $\mathrm{C}=$ curved

\subsection{Analysis of Bandung - Jakarta direction}

The analysis of Bandung - Jakarta direction applied the same comparison method in Jakarta - Bandung direction. The results indicate that the paired sample t-test for Bandung-Jakarta (BJ) also demonstrate significant difference of visual safety perception between the road without road lighting and the road having road lighting using either white or yellowish light as seen in Table 3 .

\subsubsection{Straight road with and without road lighting}

Significant difference of visual safety perception on the straight road without road lighting and road lighting with white light has $\mathrm{p}$ value less than 0.001 . The car drivers selected the road with white light road lighting more than the road without road lighting which supported by the mean for the road with white lighting equal to 3.43 which is higher than the mean of the road without road lighting (2.25).

The similar result for the visual safety perception on a straight road without road lighting compared to the road with road lighting using yellowish light with $p<0.001$, mean for yellowish light $=4,00$ and mean for the white light $=2.25$.

\subsubsection{Straight road with road lighting using white light versus yellowish light}

In this straight road section from Bandung to Jakarta, the car drivers prefer the yellowish light with mean $=4.0$ which is higher than the white light road lighting with, mean $=3.43$ and the $\mathrm{p}$ value is less than 0.001 . 


\subsubsection{Curved road with and without road lighting}

On the curved road of the freeway from Bandung to Jakarta, the car drivers chose the road with lighting better than the road without lighting $($ mean $=2.22)$ either with white lighting $($ mean $=3.23)$ or with yellowish lighting $($ mean $=3.82)$, p value $<0.001$.

\subsubsection{Curved road with road lighting using white light versus yellowish light}

When comparing between the yellowish lighting and white lighting, the car drivers prefer the yellowish lighting $($ mean $=3.83)$ than the white lighting $($ Mean $=3.23)$ with the $p$ value less than 0.001 .

\subsection{Analysis of traffic signs and road markings clarity with and without road lighting}

The result of paired sample t-test for the clarity of traffic signs and road markings on the straight and curved road from Jakarta to Bandung and from Bandung to Jakarta is presented in Table 5 .

\subsection{Analysis of Jakarta to Bandung direction}

Table 5 indicates significant preference to the road with road lighting than the road without road lighting on the freeway from Jakarta to Bandung.

Table 5. The test results in clarity of the traffic signs and road markings in the direction of JakartaBandung $(J)$ and Bandung - Jakarta (B) freeway with and without road lighting for the straight and curved road $(\mathrm{N}=58)$

\begin{tabular}{|c|c|c|c|c|c|}
\hline Pair & $\begin{array}{c}\text { Road Marking } \\
\text { condition }\end{array}$ & Mean & $\begin{array}{c}\text { Mean } \\
\text { difference }\end{array}$ & $\begin{array}{c}\text { Significant } \\
\text { Level }\end{array}$ & $\begin{array}{c}\text { Significant? } \\
\text { (Yes/No) }\end{array}$ \\
\hline 1 & TR_JS1 & 2.95 & - & - & - \\
\hline & TR_JS2 & 3.94 & $-0,99$ & $<0,001$ & Yes \\
\hline 2 & TR_JS1 & 2.95 & - & - & - \\
\hline & TR_JS3 & 3.35 & $-0,40$ & $<0,004$ & Yes \\
\hline 3 & TR_JC1 & 2.77 & - & - & - \\
\hline & TR_JC2 & 3.65 & $-0,88$ & $<0,001$ & Yes \\
\hline 4 & TR_JC1 & 2.77 & - & - & - \\
\hline & TR_JC3 & 3.83 & $-1,07$ & $<0,001$ & Yes \\
\hline 5 & TR_BS1 & 2.49 & - & - & - \\
\hline & TR_BS2 & 3.42 & -0.93 & $<0,001$ & Yes \\
\hline 6 & TR_BS1 & 2.49 & - & - & - \\
\hline & TR_BS3 & 3.97 & $-1,49$ & $<0,001$ & Yes \\
\hline 7 & TR_BC1 & 2.61 & - & - & - \\
\hline & TR_BC2 & 3.40 & $-0,79$ & $<0,001$ & Yes \\
\hline 8 & TR_BC1 & 2.61 & - & - & - \\
\hline & TR_BC3 & 3.84 & $-1,23$ & $<0,001$ & Yes \\
\hline
\end{tabular}

Note: $\mathrm{TR}=$ traffic signs and road marking, $\mathrm{S}=$ straight and $\mathrm{C}=$ curved 


\subsubsection{Straight road}

At Jakarta to Bandung direction on the straight roads, the results are significantly support the road with road lighting, either with white lighting $(\mathrm{p}<0.001)$ or yellowish lighting $(\mathrm{p}$ $<0.004)$. The car drivers are confident that the traffic signs or road markings are clearer on the road that have road lighting with white light $($ Mean $=3.94)$ and yellowish light $(\mathrm{M}=$ 3.35 ) compared to the roads without road lighting (Mean $=2.95)$.

\subsubsection{Curved road}

For the curved roads on the freeway from Jakarta to Bandung the results also support the road with road lighting better than the road without road lighting, either white lighting ( $\mathrm{p}$ $<0.001$ ) or yellowish lighting ( $\mathrm{p}<0.001)$. The car drivers believe that traffic signs and road markings are more visible on the road that have road lighting with white light (mean = 3.65 ) and yellowish light (mean $=3.83)$, whereas the traffic signs and road markings on the roads without road lighting is less clear $($ mean $=2.77)$.

\subsection{Analysis of Bandung - Jakarta direction}

Result of paired sample t-test test on Bandung-Jakarta freeway shows that there is also difference of clarity level of the traffic signs or road markings between the road without road lighting and the road with road lighting.

\subsubsection{Straight road}

For the straight roads, the difference supports the road with road lighting using either white light $(p<0.001$, mean $=3.42)$ or yellowish light $(p<0.001$, mean $=3.97)$. On the road without road lighting, the traffic signs and road markings are less visible (mean $=2.49$ ).

\subsubsection{Curved road}

The identical results are obtained for the curved roads, there is also an indication of less visible traffic signs and road markings on the road without road lighting. The difference has the $\mathrm{p}$ value $<0.001$ for the comparison between the road without road lighting and the road that has road lighting with white or yellowish light. The traffic signs or road markings are more visible on the road with white lighting $($ mean $=3.40)$ and yellowish light (mean = 3.84 ) compared to the roads without road lighting (mean $=2.61)$.

Based on above analysis and the statement 'yes' in the statement column that has been shown in Table 5, it is obvious that the car drivers can clearly recognize the traffic signs and road markings on Cikampek and Cipularang freeway that equipped with road lighting either on the straight or curved roads.

\section{Conclusions}

Build upon the research results it can be concluded that the car drivers on the Cikampek and Cipularang freeway feel safer with the availability of the road lighting either with white 
light or yellowish light on the straight and curved road for both Jakarta-Bandung and Bandung-Jakarta directions. The results are corresponding to the research of Fotios et al [9] which mentions that the pedestrians feel more reassured when walking after dark around the residential area.

The visual safety perception is greater with a yellowish light road lighting compared to white light. This result is diverse from other researches, for example: Fotios [9] stated that road lighting with white light provide safer feeling than yellowish light; while Knight [15] expressed that people perceive white light to be more comfortable and safer than the yellowish light; and Morante [11], reported that road lighting with white light provide higher perceived safety than yellowish light.

The different of the results might be related to the facts that the research in Cikampek and Cipularang freeway used the existing lighting condition without any control to all the variables. The existing lighting condition at the time of the research used LED $50 \mathrm{~W}$ (white light) with the mounting height is $7.5 \mathrm{~m}$ and HPS150 $\mathrm{W}$ (yellowish light), with the mounting height is $11 \mathrm{~m}$ (see table 2) with an exception for the straight road lighting which utilized the LED $90 \mathrm{~W}$ white light and HPS150 W (yellowish light). To match with other researchers the study must applied the lighting condition using lamps with the same flux luminous and in the same road conditions.

The presence of road lighting provides clarity in recognizing traffic signs and road markings for car drivers on the straight and curved roads.

\section{Acknowledgment}

Thanks to Ministry of Education and Culture for the research funding of the doctoral program. Additional thanks to PT Jasa Marga, Tbk, Purbaleunyi branch who has provided the secondary data on Cipularang freeway, which is very useful in this research.

\section{References}

1. Eloholma, M., Ketomäki, J., Halonen, L., Meas. and An, Luminances and Visibility in Road Lighting - Conditions (2004)

2. Li, F., Chen, Y., Liu, Y., and Chen, D., Leukos VIII-3, Comparative In Situ of LEDs and HPS in Road Lighting, 205 - 214, (2012)

3. Armanto, R. Soelami, N., Soegijanto, Proc. SENVAR/2nd ISESEE 9th, Evaluation on Lighting Condition and Visual Legibility of Road Surface and Traffic sign in Bandung City (2008).

4. Setyaningsih, E., Fat, J., Zureidar, I. And Wardhani, L., Proc. EECCIS, $7^{\text {th }}$, Performance Of LED Lights Installed on DKI Jakarta Streets, (UB, Malang, 2014)

5. Santoso, W.J., Study of Public Road Lighting Supply in Jakarta East Area (Perpustakaan ITB, Bandung, 2009)

6. Ministry of Public Works, Guideline of Inter-city Road Geometric Plan (1997).

7. Putranto, L.S., Rekayasa Lalu-lintas Edisi 2 (PT Indeks, Jakarta 2013)

8. PT. Jasa Marga Tbk, Rekapitulasi Data Kecelakaan Ruas Dawuan-Padalarang Barat, Jawa Barat (2011-2015)

9. Fotios, S, Proc. CIE 2014. Lighting Quality and Energy Efficiency, Road Lighting And Pedestrian Reassurance After Dark:A Review Of The Evidence (2014) 
10. Haans, A. and de Kort, Y.A.W., Env. Psy. 32, Light distribution in dynamic street lighting: Two experimental studies on its effects on perceived safety, prospect, concealment, and escape (The Netherlands, 2012)

11. Morante, P, Fnl. Rep. for Groton Utl, Groton, Connecticut, Mesopic Street Lighting Demonstration and Evaluation. (USA, Troy, 2008)

12. Lewis, A.L., Illum. Eng. Soc., Wtr.99, Visual Performance as a Function of Spectral Power Distribution of Light Sources at Luminances Used for General Outdoor Lighting, (1999).

13. Murti, Validitas dan Realibilitas Pengukuran (UNS, Solo. 2011)

14. Privitera, G.J., Statistic for the Behavioural Science $2^{\text {nd }}$ Ed. (Sage Publication Inc,, Canada, 2015)

15. Knight, C, Light. Res. Tech., 42-3, 313-330, Field Surveys investigating the effect lamp spectrum on the Perception of Safety and Comfort at Night (2014) 